\title{
Peanut Cultivar Differences in Yield Based on Source and Sink Characteristics
}

\author{
Iskandar Lubis $^{1 *}$, Heni Purnamawati ${ }^{1}$, Roedhy Poerwanto ${ }^{1}$, Yudiwanti ${ }^{1}$, \\ Ahmad Ghozi Mansyuri ${ }^{2}$, and Sri Astuti Rais ${ }^{3}$ \\ ${ }^{1}$ Department of Agronomy and Horticulture, Faculty of Agriculture, Bogor Agricultural University \\ Jl. Meranti, Kampus IPB Darmaga 16680, Indonesia \\ ${ }^{2}$ Legume and Tuber Crops Research Center, Indonesian Department of Agriculture \\ J1. Raya Kendalpayak Km 8, PO Box 66, Malang, Jawa Timur 65101, Indonesia \\ ${ }^{3}$ Agriculture Genenetic Research and Biotechnology Research and Development Center \\ Indonesian Ministry of Agriculture, Jl. Tentara Pelajar No. 3A, Bogor 16114, Indonesia
}

Received 22 May 2012/Accepted 28 September 2012

\begin{abstract}
This research was conducted to determine peanut cultivar differences in sink and source sizes as represented by vegetative growth and yields. Two sets of experiments were conducted at Bogor Agricultural University farms, Sawah Baru and Cikarawang (06 33', S, 106 45 'E, 250 m altitude). Planting was conducted on June 12 and June 20, 2007 using 20 local and national cultivars in each location. Both experiments used randomized complete block design with three replications. Data were analyzed using correlation and regression analysis. Size of experimental unit was $1.6 \mathrm{~m} \times 4.0 \mathrm{~m}$, with planting density 125,000 plants $\mathrm{ha}^{-1}$. Urea, SP36 and $\mathrm{KCl}$ were applied at planting date in the rate of (kg ha $\mathrm{s}^{-1} 45 \mathrm{~N}_{1} 100 \mathrm{P}_{2} \mathrm{O}$ and $50 \mathrm{~K}_{2} \mathrm{O}$. Four stages of plant growth were studied: 25 days after planting (DAP); 6 weeks after planting (WAP); 10 WAP (pod filling) and 14 WAP (harvest). Five plants were sampled at 25 DAP, two plants at 6 WAP, 10 WAP and 14 WAP, and separated into leaves, stems, roots and pods. The average yield of two experimental stations showed that Biawak cultivar had the highest yield due to relatively higher aboveground dry weight (source), pod filling percentage and maximum number of gynophor+pods (potential sink). Jepara cultivar had the lowest yield due to low pod filling percentage and potential sink, although its source was considered to be in the medium category. Above ground dry weight at 6 and 10 WAP had close relation with Crop Growth Rate (CGR) during 25 DAP-6 WAP and 6-10 WAP, and the higher CGR during those periods were more related to leaf area index than to single leaf photosynthetic capacity.
\end{abstract}

Keywords: crop growth rate, pod filling percentage, leaf area index, single leaf photosynthetic capacity

\section{ABSTRAK}

Penelitian dilaksanakan untuk mempelajari perbedaan kultivar dalam ukuran sink dan source yang digambarkan oleh pertumbuhan vegetatif dan hasil. Dua set percobaan dilaksanakan Kebun Sawah Baru dan Cikarawang (06 33', S, $106^{\circ} 45^{\prime}$ T, $250 \mathrm{~m}$ dpl), Institut Pertanian Bogor. Penanaman dilaksanakan pada tanggal 12 dan 20 Juni 2007, menggunakan 20 varietas lokal dan nasional di ke-2 lokasi. Desain percobaan yang digunakan adalah rancangan kelompok lengkap teracak dengan tiga ulangan. Data dianalisis menggunakan regresi dan korelasi. Unit percobaan berukuran $1.6 \mathrm{~m} x 4.0 \mathrm{~m}$ dengan populasi 125,000 tanaman ha-1, Urea, SP36 dan $\mathrm{KCl}$ diberikan pada saat penanaman dengan dosis $\left(\mathrm{kg} \mathrm{ha}^{-1}\right) 45 \mathrm{~N}$ $100 \mathrm{P}_{2} \mathrm{O} 5$ dan $50 \mathrm{~K}_{2} \mathrm{O}$. Pengambilan sampel secara destruktif dilakukan sebanyak empat kali, yaitu pada fase 25 hari setelah tanam (HST); 6 minggu setelah tanam (MST); 10 MST (pengisisian biji); dan 14 MST (panen). Lima tanaman diambil saat 25 HST, dua tanaman pada 6, 10 dan 14 MST, dipisahkan menjadi akar, batang, daun dan polong. Dari rata-rata hasil dua kebun percobaan, terlihat bahwa kultivar Biawak mencapai hasil tertinggi melalui bobot bagian atas tanaman yang tinggi (source), persentase pengisisan biji dan jumlah maksimum gynophor+polong (sink potensial). Bobot bagian atas tanaman pada 6 dan 10 MST mempunyai hubungan yang kuat dengan laju pertumbuhan tanaman antara 25 HST-6 MST dan 6-10 MST, dan tingginya laju pertumbuhan tanaman pada periode tersebut lebih disebabkan oleh perbedaan indeks luas daun dibanding kapasitas fotosintesis daun tunggal.

Kata kunci: indeks luas daun, kapasitas fotosintesis daun tunggal, laju pertumbuhan tanaman, persentase pengisian biji

\footnotetext{
* Corresponding author. e-mail: iskandarlbs@yahoo.com
} 


\section{INTRODUCTION}

One problem faced in peanut production is low pod filling resulting in empty pod and smaller seed. Bell and Wright (1998) found that peanut productivity in Indonesia is low due to low filled pod percentage, although population density is high. This fact indicated that lower assimilate partitioning to the pod, which also indicated unbalance between source (photosynthesis during pod filling and remobilization of accumulated carbohydrate from vegetative parts) and sink (number and size of pod).

Source and sink relationship are determined by the capacity and activity of photosynthesis (source) and the capacity, activity and competition among sinks. Crop yield is determined by the amount of dry matter accumulation or harvest index (Reddy et al., 2003). Increasing yield can be reached either through increasing dry matter accumulation and or increasing harvest index (Zang et al., 2008).

Duncan et al. (1978) showed that variation among four peanuts cultivar with runner and stand up type in America were due to three physiological processes namely partitioning of the assimilate between the reproductive and vegetative structures, the length of the pod filling period and the rate of the pod establishment. Moreover, Ketring et al. (1982), Jogloy et al. (2011a) and Jogloy et al. (2011b) reported that peanut characteristics that determined yield were pod numbers, assimilate partitioning during pod filling, and pod filling period.

Many reports showed that dry matter accumulation immediately before and at pod filling period determined the yield. Shiraiwa et al. (2004) also found that the amount of dry matter accumulation at early period of pod filling phase determined yield differences among soybean genotypes. The differences between high yielding and low yielding rice were dependent on capacity of dry matter accumulation before heading and assimilate translocation during grain filling (Miah et al., 1996). While Lubis et al. (2003) stated that yield was more affected by rice dry matter at grain filling than non structural carbohydrate (NSC) at heading.

Longevity and capacity of leaf photosynthesis is related to nitrogen $(\mathrm{N})$ status in the leaf. Two sources of $\mathrm{N}$ for seed growth during grain filling phase mainly $\mathrm{N}$ absorbed by root, and remobilisation from vegetative organ (Andersson, 2005). Delay of leaf $\mathrm{N}$ remobilisation can maintain photosynthetic capacity longer, and probably can increase seed yield. Leaf area index also affect the capacity of crop photosynthesis and can be used as an indicator for period of leaf greenness. The other environmental growth conditions also affect growth and yield performances such as water status (Riadi et al., 2008; Evita, 2010) and cropping pattern (Buhaira, 2007). This research was aimed to clarify varietal differences in sink and source size, and their contribution to the yield, as a part of serial research that aimed to increase peanut productivity in Indonesia.

\section{MATERIAL AND METHOD}

The experiments were conducted at Bogor Agricultural Universities' farms, Sawah Baru and Cikarawang (06 33',
$\mathrm{S}, 106^{\circ} 45^{\prime}, 250 \mathrm{~m}$ altitude). Planting was conducted on June 12 and June 20, 2007, using 20 local and national peanut cultivars in each location. Designs of experiment were randomized complete block design with three replications. Data were analyzed using correlation and regression analysis. Size of experimental unit was $1.6 \mathrm{~m} \mathrm{x} 4.0 \mathrm{~m}$, with planting density 125,000 plants $\mathrm{ha}^{-1}$. Urea, SP36 and $\mathrm{KCl}$ were applied at planting date in the rate of $\left(\mathrm{kg} \mathrm{ha}^{-1}\right) 45 \mathrm{~N}$, $100 \mathrm{P}_{2} \mathrm{O}_{5}$ and $50 \mathrm{~K}_{2} \mathrm{O}$.

Four stages of plant growth were studied, namely 25 days after planting (DAP); 6 weeks after planting (WAP); 10 WAP (pod filling) and 14 WAP (harvest). Five plants taken in 25 DAP, two plants in 6,10 and 14 WAP, and were separated into leaves, stems, roots and pods. Leaf area was measured with gravimetric method. All sample parts were oven-dried at $60{ }^{\circ} \mathrm{C}$ for 3 days weighted, then prepared for Nitrogen and non structural carbohydrates (NSC) analysis.

Photosynthesis and transpiration was measured at the sampling time using Gas Exchange System LCA-4 (ADC Bio-Scientific) at 08.00 to $10.00 \mathrm{a} . \mathrm{m}$. for photosynthesis, and at 19.00 p.m. for respiration in two plants at 6 and 10 WAP in Cikarawang experimental station. Two leaves from primary branch (the third from upper leave) were taken in 6 and $10 \mathrm{WAP}$ at 08.00-09.00 a.m. for chlorophyl measurement.

Harvest was done at $14 \mathrm{WAP}$, from two middle rows of experimental unit (5 plants), and separated into pods and stems and leaves, weighted, and air dried for 3-5 days. After drying, seeds were taken from the pods and again air dried to $8 \%$ water content. Productivity and its components were observed, as pod number and weight, filled and unfilled (empty) pod numbers, 100 seeds weight, ratio seed with pod and harvest index.

Oven dried leaf and stem of 8 varieties were analyzed for N and NSC contents in Food Services Laboratorium of Food Science and Technology Department, Faculty of Agricultural Mechanization and Technology, Bogor Agricultural University. Total non-structural Carbohydrate (TNC) was adjusted from proximate and crude fiber, while $\mathrm{N}$ was analyzed with Kjeldahl method.

\section{RESULT AND DISCUSSION}

Soil analysis showed that similar soil fertillity was found from two experimental stations, however soil in Sawah Baru station was more compact than Cikarawang station. At peanut initial growth phase, Sawah Baru were disturbed by the broken irrigation system for 3 weeks, thus the peanuts growth were affected.

\section{Yield and Dry Matter Production}

Seed yield ranged from 0.96 ton ha $^{-1}$ of cultivar Jepara to 1.66 ton $\mathrm{ha}^{-1}$ of cultivar Biawak, and aboveground dry weight ranged from 2.37 ton $\mathrm{ha}^{-1}$ of cultivar Garuda 3 to 5.04 ton ha ${ }^{-1}$ of cultivar Sima (Table 1).

From average yield of the two stations, it was shown that cultivar Biawak had the highest yield due to relatively higher aboveground dry weight (potential source), filled 
pod percentage and maximum number of gynophor + pods (potential sink). While cultivar Jepara had the lowest yield due to lower filled pod percentage and potential sink.

Peanut pod numbers per square meter increased from 6 to 14 WAP (Table 2). Number of pod per square meter ranged from 7.3 of Rusa to 86.5 of Kelinci at 6 WAP, from 117.7 of Mahesa and Badak to 237.5 of Biawak at 10 WAP, and from 191.7 of Badak to 368.8 of Rusa at 14 WAP. The relationship between pod number with yield showed that number of pod per square meter at 10 WAP has closer relation $\left(\mathrm{r}=0.51^{*}\right)$ than the relation of number of pod at 6 $\operatorname{WAP}\left(\mathrm{r}=0.21^{\mathrm{ns}}\right)$ or $14 \mathrm{WAP}\left(\mathrm{r}=0.30^{\mathrm{ns}}\right)$. This fact indicates that number of pod at $10 \mathrm{WAP}$ is one of important factors that related to yield formation. Many pods that formed during 10-14 WAP may not be supplied with enough assimilate during pod filling due to their late formation, while number of pod that formed at 6 WAP may not reflect the true number of final pod.

When aboveground growth rate is correlated with yield, it indicated that some cultivars such as Biawak, Landak, Gajah and Jerapah may utilize non structural carbohydrate that remobilize from aboveground part to the pods, because they have negative aboveground growth rate during pod filling (10-14 WAP), while the other cultivars such as Sima, Simpai and Garuda 2 may only depended on photosynthesis during pod filling (Figure 1).

\section{Crop Growth Rate}

Relationship between crop growth rate (CGR) and aboveground dry weight showed that aboveground dry weight at 6 WAP had close relation with CGR during 25 DAP-6 WAP $\left(\mathrm{r}=0.95^{* *}\right)$ and aboveground dry weight at 10 WAP had close relation with 6-10 WAP $(\mathrm{r}=0.93 * *)$. Those relations were closer than the relation of aboveground dry weight at 14 WAP with CGR during 10-14 WAP $(\mathrm{r}=0.54 *)$. This result is in accordance with analysis that had been done by Purnamawati et al. (2010) which concluded that peanut with higher biomass accumulation at initial growth (26-42 DAP) would produce higher yield. Considering the possibility of assimilate remobilization during pod filling and the role of dry matter production during pod filling to the yield performance, this fact may indicate potential contribution of biomass production to the yield performance.

Table 3 also showed close relation between CGR during 6-10 WAP and number of pods at 10 WAP $(r=$ $0.60 *)$, and it was closer than the relationship between CGR 25 DAP-6 WAP and number of pods at 6 DAP $\left(r=0.44^{*}\right)$ or relation between CGR 10-14 WAP and number of pods at 14 WAP $\left(r=0.24^{\mathrm{ns}}\right)$. According to the closer relation of number of pod at 10 WAP to the yield, the relation of CGR during 6-10 WAP to the number of pod at 10 WAP may indicate

Table 1. Aboveground dry weight, maximum gynophor+pods number, pod filling percentage and seed yield of peanuts cultivars

\begin{tabular}{|c|c|c|c|c|}
\hline Cultivar & $\begin{array}{l}\text { Aboveground dry } \\
\text { weight (ton } \mathrm{ha}^{-1} \text { ) }\end{array}$ & $\begin{array}{c}\text { Max. gyn+pods } \\
\text { number } \mathrm{m}^{-2}\end{array}$ & $\begin{array}{c}\text { Pod filling } \\
\text { percentage }(\%)\end{array}$ & 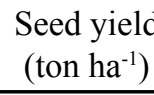 \\
\hline Biawak & 3.60 & 520.9 & 67.0 & 1.66 \\
\hline Garuda 2 & 3.60 & 481.3 & 61.4 & 1.50 \\
\hline Panter & 3.35 & 687.5 & 71.7 & 1.47 \\
\hline Sima & 5.04 & 494.8 & 62.5 & 1.37 \\
\hline Kelinci & 2.98 & 742.8 & 61.5 & 1.34 \\
\hline Jerapah & 2.48 & 415.6 & 63.4 & 1.32 \\
\hline Kidang & 3.81 & 392.8 & 72.3 & 1.29 \\
\hline Kancil & 3.35 & 603.1 & 69.6 & 1.26 \\
\hline Macan & 2.93 & 333.4 & 70.2 & 1.25 \\
\hline Simpai & 3.96 & 427.1 & 61.6 & 1.24 \\
\hline Pelanduk & 3.34 & 337.5 & 66.2 & 1.20 \\
\hline Landak & 3.80 & 498.9 & 57.9 & 1.19 \\
\hline Badak & 2.52 & 577.1 & 65.7 & 1.18 \\
\hline Gajah & 2.41 & 583.4 & 59.3 & 1.18 \\
\hline Rusa & 3.47 & 504.2 & 58.2 & 1.14 \\
\hline Garuda 3 & 2.37 & 423.9 & 66.3 & 1.12 \\
\hline Turangga & 4.96 & 602.1 & 53.5 & 1.08 \\
\hline Mahesa & 3.07 & 347.9 & 68.4 & 1.06 \\
\hline Zebra & 2.83 & 766.6 & 59.9 & 1.03 \\
\hline Jepara & 3.23 & 452.1 & 57.6 & 0.96 \\
\hline
\end{tabular}

Note: Data are an average of 2 sets of experimental results 
Table 2. Average pod number at 6,10 and 14 weeks after planting

\begin{tabular}{|c|c|c|c|}
\hline Cultivar & 6 WAP & 10 WAP & 14 WAP \\
\hline \multicolumn{4}{|c|}{ 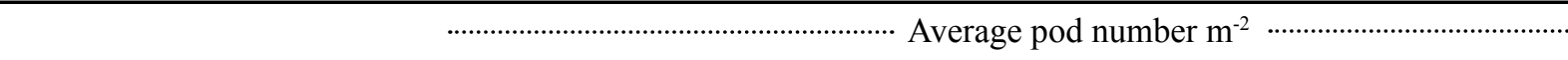 } \\
\hline Biawak & 66.7 & 237.5 & 291.6 \\
\hline Garuda2 & 18.8 & 211.4 & 355.3 \\
\hline Panter & 47.9 & 211.8 & 230.5 \\
\hline Sima & 23.9 & 201.1 & 229.1 \\
\hline Kelinci & 86.5 & 215.6 & 252.1 \\
\hline Jerapah & 40.6 & 185.4 & 310.4 \\
\hline Kidang & 44.8 & 196.9 & 213.6 \\
\hline Kancil & 83.4 & 217.7 & 261.4 \\
\hline Macan & 11.4 & 149.0 & 201.1 \\
\hline Simpai & 15.6 & 174.0 & 242.8 \\
\hline Pelanduk & 38.6 & 157.3 & 203.1 \\
\hline Landak & 37.5 & 205.2 & 263.6 \\
\hline Badak & 25.0 & 117.7 & 191.7 \\
\hline Gajah & 32.3 & 188.6 & 239.6 \\
\hline Rusa & 7.30 & 219.8 & 368.8 \\
\hline Garuda 3 & 32.3 & 183.3 & 247.9 \\
\hline Turangga & 34.4 & 155.2 & 224.0 \\
\hline Mahesa & 31.3 & 117.7 & 233.3 \\
\hline Zebra & 50.0 & 195.8 & 263.6 \\
\hline Jepara & 47.9 & 189.6 & 219.8 \\
\hline Correlation with Seed Yied (r) & $0.21^{\mathrm{ns}}$ & $0.51^{*}$ & $0.30^{\mathrm{ns}}$ \\
\hline
\end{tabular}

Notes: $\mathrm{WAP}=$ week after planting; $*=$ significant at $5 \%$ level, and ns $=$ not significant

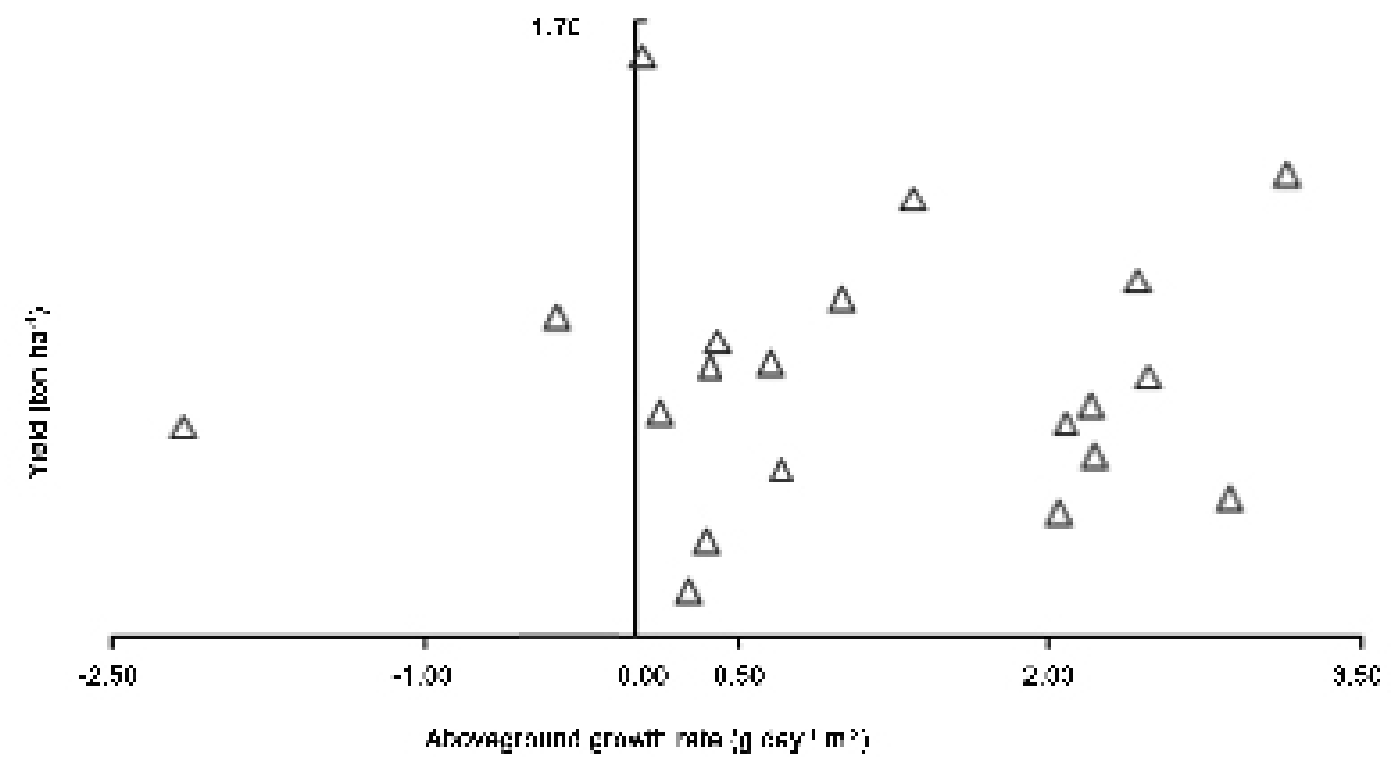

Figure 1. Above ground growth rate during 10-14 week after planting and seed yield of several peanut cultivar

the contribution of CGR during 6-10 WAP to the yield performance. From the above results, it showed that CGR during 6-10 WAP has valuable influence to aboveground dry weight at 10 WAP. Phakamas et al. (2008) found that number of pod per unit area determined the variation of pod yield among peanut genotypes, and it was influenced by crop growth rate at R6-R7 stage. While, Shiraiwa et al. (2004) found that the amount of dry matter accumulation at early 
period of grain filling phase determined yield differences among soybean genotypes.

In order to examine the factors that related to CGR during 6-10 WAP, CGR was correlated with average leaf area index (LAI) and single leaf photosynthesis (Pn). It showed that the closer relation occurred between average LAI and CGR during 6-10 WAP $\left(\mathrm{r}=0.86^{* *}\right)$ and during 25 DAP-6 WAP $\left(\mathrm{r}=0.76^{* *}\right)$ compared to its' relation at 10-14 WAP $\left(\mathrm{r}=0.18^{\mathrm{ns}}\right)$ (Table 4$)$. The close relationship between CGR and LAI during 6-10 WAP may indicate the important role of LAI during this period in contribution to yield performance. While the relation between CGR and Pn showed that Pn at 10 WAP had close relation with CGR during 10-14 WAP $\left(\mathrm{r}=0.66^{*}\right)$ compare to the other relation of CGR and Pn $\left(r=0.27^{\text {ns }}\right.$ and $\left.r=0.10^{\text {ns }}\right)$. This fact also indicates that Pn may have much contribution than LAI in later period of growth. Leaf area index affected the capacity of crop photosynthesis and could be used as an indicator for period of leaf greenness. Leaf area index determined amount of solar radiation that could be absorbed by the canopy, and then affected photosynthesis, assimilate translocation and yield.

Table 3. Correlation between crop growth rate and pod number or aboveground dry weight

\begin{tabular}{|c|c|c|c|}
\hline Period of crop growth rate & Pod number & Aboveground dry weight & $\begin{array}{l}\text { Stage of pod number and } \\
\text { aboveground dry weight }\end{array}$ \\
\hline 25 DAP-6 WAP & $0.44 *$ & $0.95 * *$ & 6 WAP \\
\hline 6-10 WAP & $0.60 *$ & $0.93 * *$ & $10 \mathrm{WAP}$ \\
\hline 10-14 WAP & $0.24^{\mathrm{ns}}$ & $0.54 *$ & 14 WAP \\
\hline
\end{tabular}

Notes: $\mathrm{DAP}=$ days after planting and WAP is weeks after planting; $* *=$ significant at $1 \%$ level; $*=$ significant at $5 \%$ level, and ns not $=$ significant

Table 4. Correlation between crop growth rate and leaf area index or photosynthetic capacity of single leaf

\begin{tabular}{lccc}
\hline $\begin{array}{l}\text { Period of crop growth rate } \\
\text { and leaf area index }\end{array}$ & Average leaf area index & $\begin{array}{c}\text { Single leaf photosynthetic } \\
\text { capacity }\end{array}$ & $\begin{array}{c}\text { Stage of single leaf } \\
\text { photosynthetic capacity }\end{array}$ \\
\hline 25 DAP-6 WAP & $0.75^{* *}$ & 0.26 & 25 DAP \\
6-10 WAP & $0.85^{* *}$ & 0.10 & 6 WAP \\
$10-14$ WAP & $0.17^{\text {ns }}$ & 0.66 & 10 WAP \\
\hline
\end{tabular}

Notes: $* *=$ significant at $1 \%$ level; $\mathrm{ns}=$ indicates not significant

\section{CONCLUSIONS}

Cultivar Biawak had the highest yield due to relatively higher aboveground dry weight (source), filling percentage and maximum number of gynophor + pods (potential sink). Cultivar Jepara had the lowest yield due to low filling percentage and potential sink, although its source counted as a medium categories. Above ground dry weight at 6 WAP and 10 WAP had close relation with crop growth rate during 25 DAP-6 WAP and 6-10 WAP, and the higher crop growth rate during those period were more related to leaf area index than to single leaf photosynthetic capacity.

\section{ACKNOWLEDGEMENT}

Our gratitude to Development and Research Board of Indonesian Ministry of Agriculture which has funded this research in collaboration with Bogor Agricultural University under KKP3T Programme.

\section{REFERENCES}

Andersson, A. 2005. Nitrogen redistribution in spring wheat. Thesis. Swedish University of Agricultural Sciences. Alnarp.

Bell, M.J., G.C. Wright. 1998. Groundnut growth and development in contrasting environment. 1. Growth and plant density responses. Exp. Agric. 34:99-112.

Buhaira. 2007. Respons kacang tanah (Arachys hypogaea L.) dan jagung (Zea mays L.) terhadap beberapa pengaturan tanam jagung pada sistem tanam tumpang sari. J. Agronomi 11:41-45.

Duncan, W.G., D.E. McCloud, R.L. McGraw, K.J. Boote. 1978. Physiological aspects of peanut yields improvement. Crop Sci. 18:1015-1020. 
Evita. 2010. Respon tanaman kacang tanah (Arachis hypogaea L.) terhadap cekaman air. Percikan 3:1-4.

Jogloy, C., P. Jaisil, C. Akkaseng, T. Kesmala, S. Jogloy. 2011a. Heritability and correlation of crop partitioning in advanced generations of peanut crosses. Asian J. Plant Sci. 10:60-66.

Jogloy, C., P. Jaisil, C. Akkaseng, T. Kesmala, S. Jogloy. 2011b. Heritability and correlation for maturity and pod yield in peanut. J. Appl. Sci. Res. 7:134-140.

Ketring, D.L., R.H. Brown, G.A. Sullivan, B.B Johnson. 1982. Growth Physiology. In H.E. Pattee, C.T Young $(E d s$.$) . Peanut Science and Technology. American$ Peanut Research and Education Society, Inc., Texas.

Lubis, I., T. Shiraiwa, M.Ohnishi, T.Horie, N. Inoue. 2003. Contribution of sink and source sizes to yield variation among rice cultivars. Plant Prod. Sci. 6:119-125.

Miah, M.N.H., T. Yoshida, Y. Yamamoto, Y. Nitta. 1996. Characteristics of dry matter production and partitioning of dry matter in high yielding semi dwarf indica and japonica-indica hybrid rice varieties. Jpn. J. Crop. Sci. 65:672-685.
Phakamas, N., A. Patanothai, S. Jogloy, K. Pannangpetch, G. Hoogenboom. 2008. Physiological determinants for pod yield of peanut lines. Crop Sci. 48:23512360 .

Purnamawati, H., R. Poerwanto, I. Lubis, Yudiwanti, S.A. Rais, A.G. Manshuri. 2010. Accumulation and distribution of plant dry matter in peanut cultivars . J. Agron. Indonesia 38:100-106.

Reddy, N.Y.A., R.U. Shaanker, T.G. Prasad, M.U. Kumar. 2003. Physiological approaches to improving harvest index and productivity in sunflower. Helia 26:81-90.

Riadi, M., L. Soetopo, N. Basuki, A. Kasno. 2008. Tingkat potensial air tanah sebagai lingkungan seleksi kacang tanah terhadap cekaman kekeringan. J. Agrivigor $7: 254-262$.

Shiraiwa, T., N. Ueno, S. Shimada, T. Horie. 2004. Correlation between yielding ability and dry matter productivity during innitial seed filling stage in various soybean genotypes. Plant Prod. Sci. 7:138142.

Zhang, X., S. Chen, H. Sun, D. Pei, Y. Wang. 2008. Dry matter, harvest index, grain yield and water use efficiency as affected by water supply in winter wheat. Irrigation Sci. 27:1-10. 